\title{
Replacing the maize by enzymatic treated Bajra in broiler diet
}

\begin{abstract}
Arun Kumar
ABSTRACT : The poultry do not have enzyme to break down fibre completely and need a such enzyme which has a capability to break down in energy without any harmful impact on body growth, blood metabolities and meat quality. In order, the biotechnology aspect to improve feed value by the use of enzyme in poultry feed. The aim of present study was to use the crude fibre rich cereal Bajra instead of maize with enzyme where the availability of maize is short. The experiment was conducted at poultry farm of C.S.A. University of Agriculture and Tech., Kanpur with 30 day-old-chicks. Chicks were selected and divided randomly into five groups for different treatment namely $\mathrm{G}_{1}, \mathrm{G}_{2}, \mathrm{G}_{3}, \mathrm{G}_{4}$ and $\mathrm{G}_{5}$ consisting of 6 bird in each and maize were replaced with Bajra by 10 per cent, 20 per cent, 30 per cent and 40 per cent for $\mathrm{G}_{2}, \mathrm{G}_{3}, \mathrm{G}_{4}$ and $\mathrm{G}_{5}$, respectively and $\mathrm{G}_{1}$, treated as control group.
\end{abstract}

KEY WORDS : Enzyme, Poultry, Bajra

HOW TO CITE THIS PAPER : Kumar, Arun (2020). Replacing the maize by enzymatic treated Bajra in broiler diet. Res. J. Animal Hus. \& Dairy Sci., 11(1) : 1-5 : DOI: 10.15740/HAS/RJAHDS/11.1/1-5. Copyright@ 2020: Hind Agri-Horticultural Society. 